\title{
DETECTION OF ENTEROTOXIN GENES IN STAPHYLOCOCCUS AUREUS ISOLATED FROM COW MILK
}

\author{
KATREEN K.G. ${ }^{1}$; HAMS M.A. MOHAMED ${ }^{2}$; M.W. ABD AL-AZEEM ${ }^{2}$ and \\ F. ABDEL-LATIF WASSEL ${ }^{1}$ \\ ${ }^{1}$ Animal Health Research Institute, Sohag, Egypt \\ ${ }^{2}$ Department of Microbiology, Faculty of Veterinary Medicine, South Valley \\ University, Qena, Egypt
}

Received: 25 July 2018; Accepted: 4 September 2018

\begin{abstract}
Staph. aureus is considered one of the main causes of food poisoning and clinical infections in different hosts. So this work intended to investigate the occurrence of enterotoxin genes and antibiotics susceptibility of Staph aureus isolated from raw and local pasteurized milk. To realize this, 125 samples of raw milk and 75 samples of local pasteurized milk were obtained from supermarkets, dairy shops and farms in Sohag Province, Egypt. These samples were subjected to bacteriological examination. The result showed that 68 out of 125 raw milk samples and 37 out of 75 local pasteurized milk samples were positive for Staphylococcus spp. on mannitol salt agar. Biochemical scheme supposed that 18 isolates of raw milk samples and 8 isolates of local pasteurized milk samples were positive for staph aureus. PCR by using nuc gene specific primer, discriminated the existence of Staph aureus DNA in 15 isolates out of 18 isolates of raw milk samples, while 7 isolates out of 8 isolates of local pasteurized milk samples showed a postive bands at 267bp. Staphylococcal enterotoxin genes were detected in $53.33 \%$ and $42.86 \%$ of Staph aureus isolates from raw and local pasteurized milk, respectively. sea and sed genes were detected in most isolates of Staph aureus while none of these isolates harbored seb and see genes. sec gene could be detected only in the raw milk isolates. The antibiotics sensitivity profile of enterotoxigenic Staph aureus was showed a high percentage of resistance to penicillin and tetracycline while all isolates were fully susceptible to vancomycin.
\end{abstract}

Key words: Milk, Staph aureus, nuc gene, enterotoxins, antimicrobials.

\section{INTRODUCTION}

Milk is an imperative food because it is rich by various essential components including proteins, vitamins, and minerals also it considers a nutritive media for many microorganisms such as Staph. aureus which mainly criminalized in food poisoning cases (Pandey et al., 2014), because it can adapt to grow in various types of foods and secreting enterotoxins (Balaban and Rasooly,2000).

The contamination of milk by Staph. aureus was occurred through the infection of the mammary gland or by bad sanitary conditions, during or after milking, and these happened by human activity who responsible for the contamination (Rehman et al., 2014)

Staph. aureus is a gram-positive microorganism, grows in a different temperatures, ranged from 7 "C

Corresponding author: KATREEN K.G

E-mail address: Katreen_Samy@hotmail.com

Present address: Animal Health Research Institute, Sohag, Egypt to 48.5 "C. It produce a broad extracellular toxins, the antigenic-base classification of Staphylococcal enterotoxins (SEs) includes five classical types of toxins (SEA- SEE) (Riva et al.,2015). The most imperative SEs are SEA and SEB which usually more common in milk (Chiang et al., 2006).

Staphylococcal enterotoxins resists the majority of proteolytic enzymes and thus remains their action in gastrointestinal tract. They are highly heat resistant toxin (Sutejo et al., 2017), they keep their activities even after pasteurization (Ralln et al., 2008).The SEs toxins resulting in nausea, brutal vomiting, abdominal pain and occasionally diarrhea (Rosengren et al., 2013).

Staph. aureus became more complicated problem for it's ability to resist different types of antibiotics. The spreading of the MRSA strains worldwide lead to high costs in terms of treatment and lead to life threatening infections (Yamamoto et al., 2013).

Routine identification of Staph. aureus usually carried out by traditional methods but these methods 
were discomfit and time consuming. Furthermore, these methods lead to indistinct results. Rapid and accurate methods for identification of food borne pathogens are important for microbiological safety. In the last 10 years, unrestricted detection methods using molecular techniques, suth as polymerase chain reaction (PCR) method particularly multiplex PCR was proven as one of the most suitable way for sensitive and fast detection of pathogenic bacteria in food (Shawish and Al-Humam, 2016 and Kim et al., 2017).

Considering to these facts, the existing work intended to study: The presence of SEs coding genes (sea, seb, sec, sed and see) in Staph aureus strains isolated from raw and local pasteurized milk by using multiplexPCR and evaluation the sensitivity of these isolates to different types of antimicrobials.

\section{MATERIALS AND METHODS}

\section{I-Milk samples:}

A total of 200 cow milk samples (125 raw cow milk and 75 local pasteurized cow milk) were collected randomly from local markets, street vendors and farms in Sohag Governorate, Egypt, during the period from July to September 2017. The samples were collected in sterile plastic bags. All the samples were taken to the laboratory under refrigerate conditions where they were prepared for bacteriological examination.

\section{II- Isolation of Staph. aureus:}

One milliliter of each sample was added aseptically in a sterile test tube contain $9 \mathrm{ml}$ of the nutrient broth. Inoculated test tubes were incubated at $37^{\circ} \mathrm{C}$ for 18 hours. A loopful from each incubated broth tube was plated on mannitol salt agar by using Streaking plate method. Plates were incubated at $37^{\circ} \mathrm{C}$ for $24-48$ hours according to (Arora, 2003). The suspected colonies were purified and then transferred to nutrient agar slopes for preservation and further identification.

\section{III-Biochemical Identification of Staph. aureus isolates:}

The identification of suspected colonies were identified according to Holt et al. (1993) this identification based on colony morphology, staining reaction and biochemical tests such as catalase, coagulase test and thermonuclease test. The isolates which pretended a positive results in pervious tests were submitted to the Voges-Proskauer to discriminate Staph. aureus (positive) from other coagulase and thermonuclease positive (negative).

\section{IV-Genotypic identification:}

\section{1-DNAextraction:}

DNA was extracted from $5 \mathrm{ml}$ of a coagulae-positive Staphylococcal culture grown at $35^{\circ} \mathrm{C}\left( \pm 2^{\circ} \mathrm{C}\right)$ for 16 $24 \mathrm{~h}$ in nutrient broth (oxoid). DNA was extracted by
QIAamp DNA Mini kit (Qiagen, Germany, GmbH) according to the manufacture instructions.

\section{2-Molecular confirmation of Staph aureus by using conventional PCR:}

Amplification reaction were performed according to Mansour et al. (2017) with slight modification, in a final volume of $50 \mu \mathrm{l}$ containing: $25 \mu \mathrm{l}$ PCR Mastermix (Emerald Amp GT), 1.5 $\mu$ l for each primer for nuc gene (Table. 1), $5 \mu$ l of DNA Template and $17 \mu l$ of PCR grade water. Reactions were carried out in thermal cycler (MJ Research, Inc. Watertown, MA) with the following program: initial denaturation at $94^{\circ} \mathrm{C}$ for $5 \mathrm{~min}$ followed by 35 cycles of $94^{\circ} \mathrm{C}$ for 2 min, $52^{\circ} \mathrm{C}$ for $1 \mathrm{~min}$ and $72^{\circ} \mathrm{C}$ for $1 \mathrm{~min}$ with a final extension at $72^{\circ} \mathrm{C}$ for $10 \mathrm{~min}$. PCR product was alienated by electrophoresis in $1.5 \%$ agarose gel (Bioshop $^{\mathrm{R}}$, Candainc.) stained with ethidium bromide, then visualized in a UV transilluminator.

\section{3-Detection of classical enterotoxin genes in Staph.} aureus isolates by using multiplex PCR:

Multiplex PCR was performed by using the following primers for enterotoxin genes (sea, seb, sec, sed and see) (Table 1), the PCR mixture was prepared as following: $12.5 \mu \mathrm{l}$ PCR Taq green Mastermix (Thermo), $1 \mu \mathrm{l}$ of each primer and $1 \mu \mathrm{l}$ DNA. The final volume was adjusted to $25 \mu \mathrm{l}$ by adding sterile PCR grade water. Amplification profile was standardized in $94^{\circ} \mathrm{C}$ for 5 min followed by 35 cycles of $94^{\circ} \mathrm{C}$ for $2 \mathrm{~min}, 52^{\circ} \mathrm{C}$ for $2 \mathrm{~min}$ and $72^{\circ} \mathrm{C}$ for $3 \mathrm{~min}$ with a final extension at $72^{\circ} \mathrm{C}$ for $7 \mathrm{~min}$. PCR products were separated by gel electrophoresis $(1.5 \%$ agarose gel stained with ethidium bromide) then were visualized in a UV transilluminator (Mansour et al., 2017).

\section{V-Antibiotic sensitivity Test:}

The disk diffusion technique was used according to (Mohanty and Cock, 2010), to perform the antimicrobial susceptibility test for enterotoxigenic Staph. aureus strains, $0.1 \mathrm{ml}$ of bacterial suspension ( $\left.1 \times 10^{8} \mathrm{CFU} / \mathrm{mL}\right)$ equivalent to $(0.5 \mathrm{McF}$ arland $)$ was plated on surface Mueller-Hinton agar. The plates was left for 2-5minutes for dry then antimicrobial disks were placed on surface of agar and incubated at $35^{\circ} \mathrm{C} \pm 2$ for $24-48 \mathrm{hrs}$. Different antimicrobials were used like: PencillinG, amoxicillin, amikacin, erythromycin, clindamycin, tetracycline, vancomycin and sulfamthaxazole-trimethoprime. The diameter of inhibition zone was measured for each antimicrobial agents used and the interpretation was compared with the measurements of CLSI (2018) for each antimicrobial was used.

\section{RESULTS}

The current results illustrated in (Fig.1) showed that Staphylococcal isolates were recovered from $54.40 \%$ $(68 / 125)$ of raw milk samples and $49.33 \%$ (37/75) of local pasteurized milk samples on mannitol salt agar. 
The biochemical profile revealed that the coagulase production was clear in 38 isolates out of 68 isolates of raw milk samples and 18 isolates out of 37 isolates of local pasteurized milk samples. Most of coagulase positive staphylococcal isolates of raw and local pasteurized milk declared a thermonuclease activity with percentages $78.9 \%(30 / 38)$ and in $72.2 \%$ (13/18), respectively. The positive coagulase and thermonuclease isolates were submitted to VogesProskauer test to discriminate Staph aureus, 18 out of 30 raw milk isolates and 8 out of 13 local pasteurized milk isolates were positive for Voges-Proskauer test (Table2).

PCR by using specific primer for (nuc gene), confirmed the presence of Staph aureus DNA in 15 out of 18 isolates of raw milk identified positive biochemically and in 7 out of 8 isolates from local pasteurized milk (Table 2\&Fig.2).

The data postulated in Table (3) and Fig (3\&4) revealed that enterotoxin genes were detected in 8 out of 15 Staph. aureus isolates $(53.33 \%)$ from raw milk samples and 3 out of 7 Staph. aureus isolates $(42.86 \%)$ from local pasteurized milk samples, sea and sed genes were detected in most Staph. aureus isolates, sec gene could be detected only in the raw milk isolates while seb and see genes were not detected in any Staph. aureus isolates from both raw and local pasteurized milk.

Enterotoxigenic Staph aureus ( 8 from raw milk and 3 from local pasteurized milk) were tested for their susceptibilities to eight antimicrobial agents. The data postulated in Table (4) demonstrated that a large section of enterotoxigenic Staph. aureus isolates showed resistance to penicillinG $(72.73 \%)$ and tetracycline $(72.73 \%)$. Intermediate resistance were showed against clindamycin (27.27\%) and erythromycin (18.18\%). All isolates showed a high sensitivity to vancomycin $(100 \%)$ followed by amikacin $(90.91 \%)$, sulfamethoxazole- trimethoprim $(81.82 \%)$ and amoxicillin (81.82\%).

Tables:

Table1: Primers sequence.

\begin{tabular}{|c|c|c|c|}
\hline Gene & Primers sequence $5^{\prime}$ & Size & Reference \\
\hline$n u c$ & $\begin{array}{l}\text { 5' GGTTATCAATGTGCGGGTGG '3 } \\
\text { 5' CGGCACTTTTTTCTCTTCGG '3 }\end{array}$ & 267 & $\begin{array}{l}\text { Brakstad et al. } \\
(1992)\end{array}$ \\
\hline sea & $\begin{array}{l}\text { F- 5' GGTTATCAATGTGCGGGTGG '3 } \\
\text { R-5' CGGCACTTTTTTCTCTTCGG '3 } \\
\end{array}$ & 102 & \multirow{5}{*}{$\begin{array}{l}\text { Mehrotra et } \text { al. } \\
\qquad(2000)\end{array}$} \\
\hline seb & $\begin{array}{l}\text { F-5' GTATGGTGGTGTAACTGAGC ' } 3 \\
\text { R-5' CCAAATAGTGACGAGTTAGG '3 }\end{array}$ & 164 & \\
\hline $\sec$ & $\begin{array}{c}\text { F-5'AGATGAAGTAGTTGATGTGTATGG'3 } \\
\text { R-5' CACACTTTTAGAATCAACCG '3 } \\
\end{array}$ & 451 & \\
\hline sed & $\begin{array}{c}\text { 5'CCAАTAATAGGAGAAAATAAAAG'3 } \\
\text { 5'ATTGGTATTTTTTTTCGTTC'3 }\end{array}$ & 278 & \\
\hline see & $\begin{array}{l}\text { 5'AGGTTTTTTCACAGGTCATCC'3 } \\
\text { 5'CTTTTTTTTCTTCGGTCAATC'3 }\end{array}$ & 209 & \\
\hline
\end{tabular}

Table 2: Specificity of PCR method for Staph. aureus DNA in raw and local pasteurized milk isolates.

\begin{tabular}{ccccccc}
\hline \multirow{3}{*}{ Samples } & \multicolumn{2}{c}{$\begin{array}{c}\text { Biochemical } \\
\text { identification }\end{array}$} & \multicolumn{3}{c}{ PCR } \\
\cline { 2 - 6 } & $\begin{array}{c}\text { No. of Staph aureus } \\
\text { isolates }\end{array}$ & \multicolumn{2}{c}{ No. of positive isolates } & No. of negative isolates \\
\cline { 2 - 7 } & $\mathbf{1 8}$ & No. & $\% \%^{*}$ & No. & $\%$ \\
\hline Raw milk & $\mathbf{8}$ & $\mathbf{1 5}$ & $\mathbf{8 3 . 3 3 \%}$ & $\mathbf{8 7 . 5 0 \%}$ & $\mathbf{1}$ & $\mathbf{1 2 . 6 7 \%}$ \\
\hline Pasteurized milk & & & & &
\end{tabular}

Table 3: Enterotoxigenic genes in Staph. aureus isolated from raw and local pasteurized milk samples.

\begin{tabular}{cccc}
\hline \multirow{2}{*}{ Samples } & $\begin{array}{c}\text { Total No. of Staph. } \\
\text { aureus isolates }\end{array}$ & $\begin{array}{c}\text { No. of } \\
\text { Enterotoxogenic } \\
\text { Staph. aureus isolates }\end{array}$ & $\begin{array}{c}\text { Enterotoxin genotyping } \\
\text { pattern }\end{array}$ \\
\cline { 3 - 4 } Raw milk & 15 & 1 & Sec \\
\cline { 2 - 4 } & & 3 & Sed \\
\cline { 3 - 4 } $\begin{array}{c}\text { Local pasteurized } \\
\text { milk }\end{array}$ & 7 & 1 & Sea+Sed \\
\cline { 2 - 4 } & & 2 & Sea \\
\hline
\end{tabular}


Table 4: Sensitivity of enterotoxigenic Staph. aureus isolated from raw and local pasteurized milk to different antimicrobials.

\begin{tabular}{cccc}
\hline \multirow{2}{*}{ Antibiotics } & \multicolumn{2}{c}{ No. of Enterotoxigenic Staph. aureus isolates (no =11) } \\
& Sensitive & Intermediate & Resist \\
\cline { 2 - 4 } & $3(27.27 \%)$ & $0(0 \%)$ & $8(72.73 \%)$ \\
\hline PenicillinG & $9(81.82 \%)$ & $0(0 \%)$ & $2(18.18 \%)$ \\
\hline Amoxicillin & $10(90.91 \%)$ & $0(0 \%)$ & $0(0 \%)$ \\
\hline Amikacin & $11(100 \%)$ & $0(0 \%)$ & $1(9.1 \%)$ \\
\hline Vancomycin & $9(81.82 \%)$ & $1(9.1 \%)$ & $1(9.1 \%)$ \\
\hline Sulfamethoxazole- Trimethoprim & $7(63.64 \%)$ & $3(27.27 \%)$ & $8(72.73 \%)$ \\
\hline Clindamycin & $3(27.27 \%)$ & $0(0 \%)$ & $2(18.18 \%)$ \\
\hline Tetracycline & $7(63.64 \%)$ & $2(18.18 \%)$ & \\
\hline Erythromycin & & &
\end{tabular}

\section{Figures:}

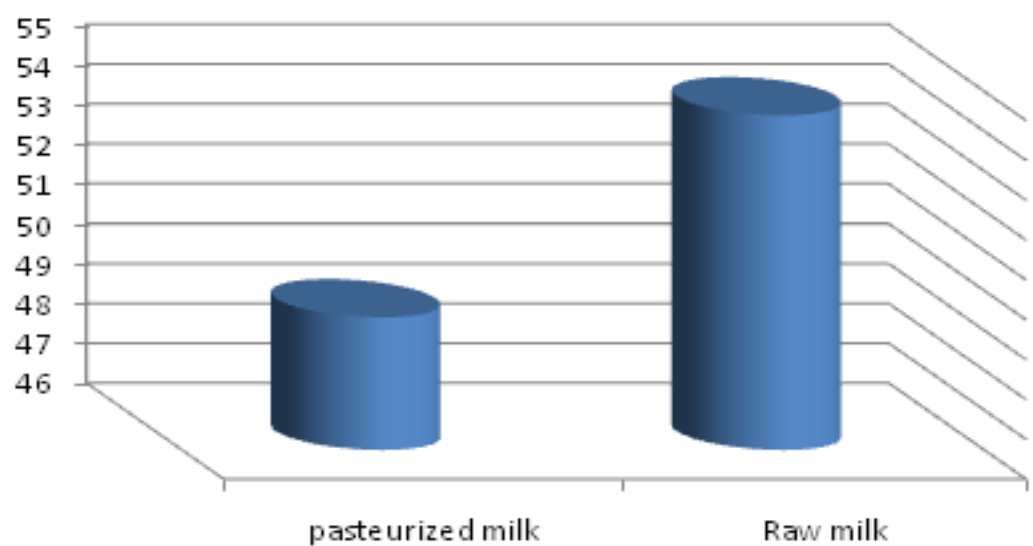

Fig. (1): Incidence of Staphylococcus spp. in raw and local pasteurized milk samples on mannitol salt agar

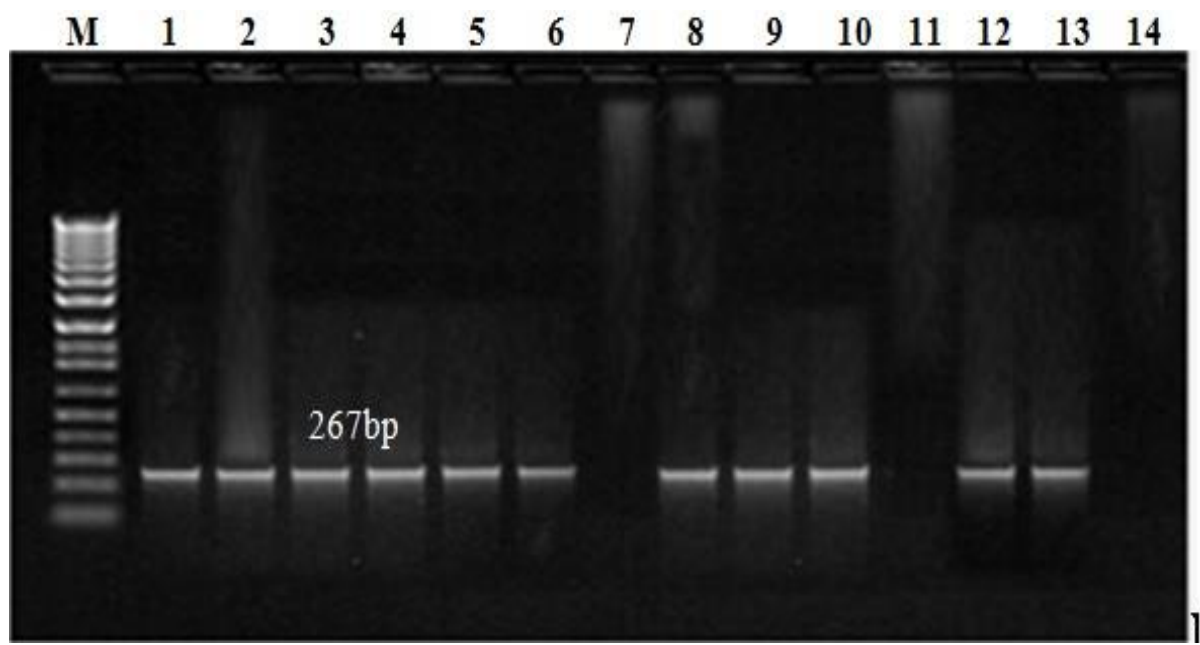

Fig. (2): Amplified profile of Staph. aureus DNA positive for nuc gene at 267bp. M: Gel Pilot 100 bp ladder (QIAGEN, no. 239035), Lane1: positive control, Lane: 2,3,4,5,6,8,9,10,12,13positive isolates, Lane 14: negative control. 


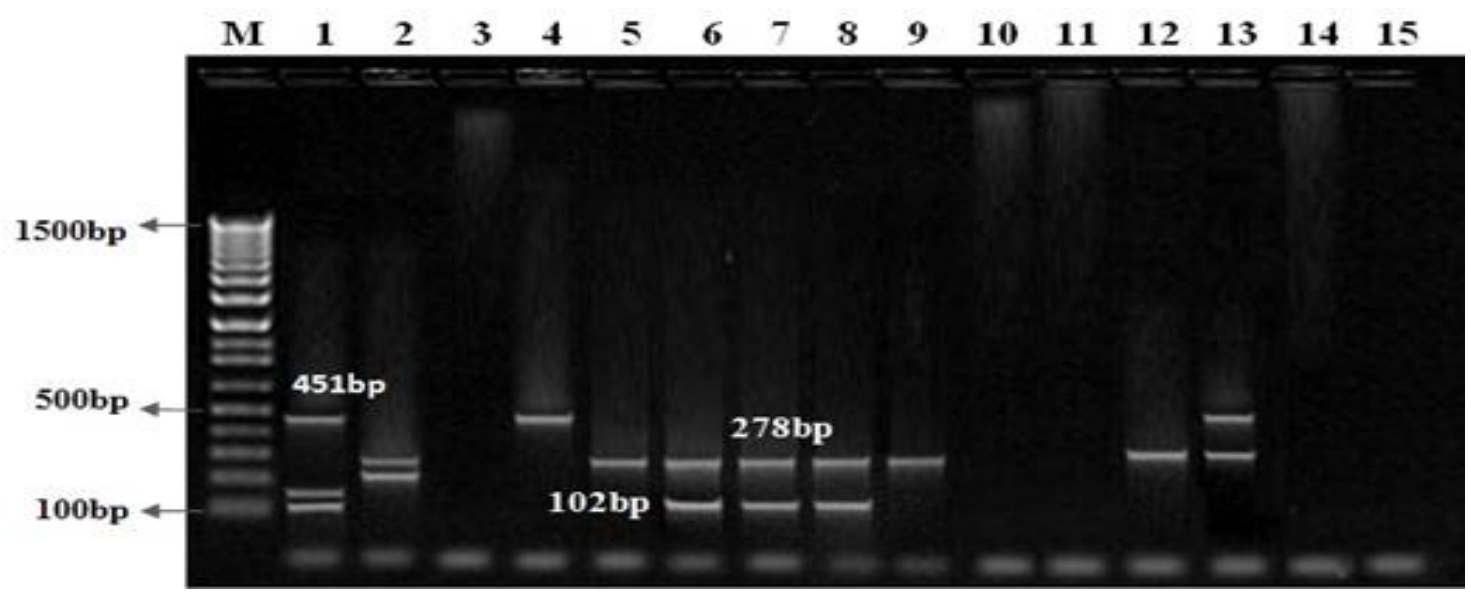

Fig. (3): Agrose gel electrophoresis of multiplex PCR products amplified from enterotoxigenic genes extracted from Staph. aureus isolated from raw milk. Lane1: positive control for sea (102 bp), seb (164 bp) \&sec (451 bp), Lane 2:positive control for see (209 bp) \& sed (278 bp) genes. Lane 4 positive isolate for sec gene, lane 5,9,12 positive isolates for sed gene, lanes $6,7,8$ positive isolate for sea and sed genes, lane 13 positive isolate for sed and $\sec$ genes and lane 15 negative control.

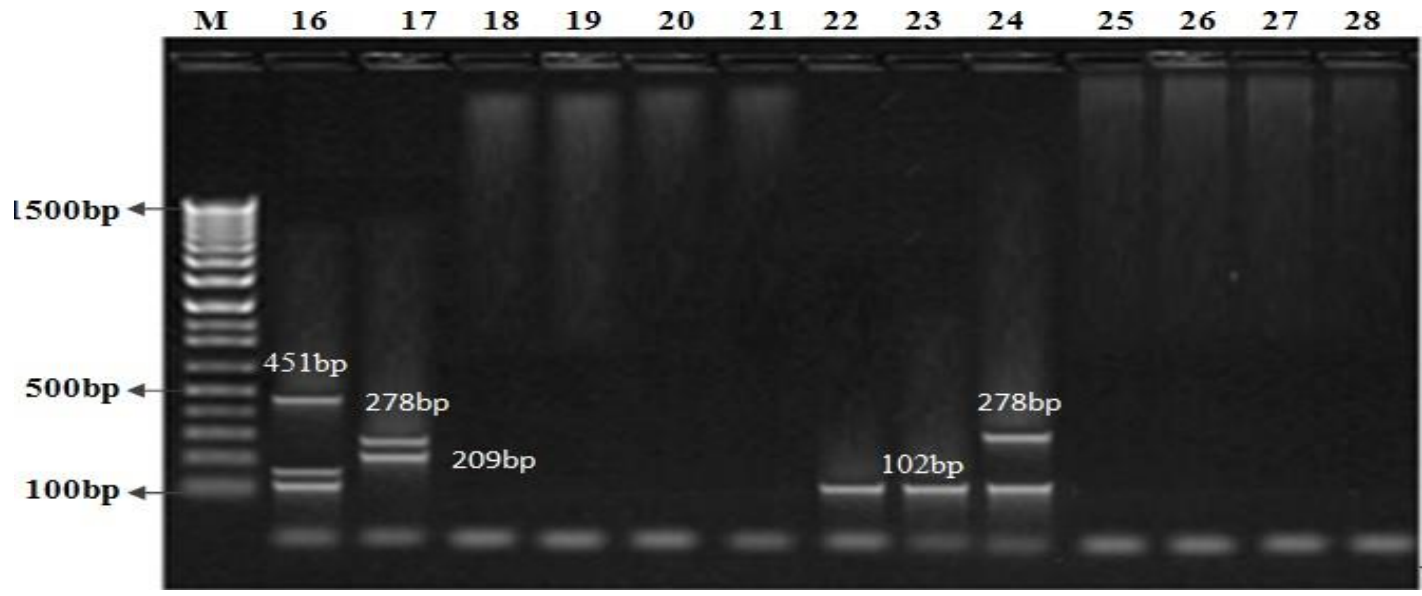

Fig. (4): Agrose gel electrophoresis of multiplex PCR products amplified from enterotoxigenic genes extracted from Staph aureus isolated from local pasteurized milk. Lane1: positive control for sea (102 bp), seb (164 bp) \&sec (451 bp), lane 2: positive control for see (209 bp) \& Sed (278 bp) genes. Lanes 22, 23 positive isolate for sea, lane 24 positive isolate for sea and sed genes and lane 28 negative control.

\section{DISCUSSION}

Staph. aureus is the principle cause of food poisoning and clinical infections in humans and animals (Chiang et al., 2006). Enterotoxigenic Staph. aureus in milk possess a public health problem to consumers. So the identification of such strain should be used as a part of a risk in analysis of milk (Zouharova and Rysanek, 2008).

The conventional identification of Staphylococcus spp. based on many diagnostic methods such as growing on selective media containing $8-10 \% \mathrm{NaCl}$, production of coagulase, thermostable nucleases and acetoin production (Kateete et al., 2010) also Quinn et al. (2002) reported that mannitol salt agar is one from the important media used specifically in food microbiology for identification of Staphylococcus spp.
Staphylococcus isolates were recovered from $54.40 \%$ of raw milk samples on mannitol salt agar (Fig.1). Nearly similar incidences of Staphylococcus spp. were showed by Ghaleb et al. (2005) $57.5 \%$ and Uddin et al. (2011) 50\%. A higher results were recorded by Daka et al. (2012) and Duguma (2018) who found that the incidences of Staphylococci were $100 \%$, and $76.2 \%$ in raw cow milk samples, respectively. On opposing with, Donkor et al. (2007) and Tessema and Tasegaye (2017) who recorded that $14.6 \%$ and $28.2 \%$ of raw milk samples were contaminated by Staphylococcus spp.

On the other hand $49.33 \%$ (37/75) of local pasteurized milk samples were contaminated by Staphylococcus spp. (Fig.1). Lower percentage was conceded by EI-Jakee et al. (2013) who detected Staphylococci species with percentage of $16 \%$ in the pasteurized milk samples. pasteurization always done at $60-65^{\circ} \mathrm{C}$ for 30 minutes and this can't kill Staph. 
aureus but reduce the level of contamination in food products, especially milk and milk products (Yaniarti et al., 2017), beside different sanitation levels during the packaging of the products (Soomro, 2003).

The variety in percentage of Staphylococcus spp. in milk may be due to different reasons include level and sources of contamination (human and animal sources), geographical regions, samples numbers and method of isolation (Fagundes and Oliveira, 2004).

The biochemical profile of our results showed that $55.88 \%$ of raw milk isolates were coagulase positive. Our result in accordance with Wani and Bhatt (2003), Abd EL-Tawab et al. (2015) and Asiimwe et al. (2017) who identified coagulase postive Staphylococci spp. from milk samples with percentage $51.1 \%, 53 \%$ and $53.57 \%$. While Kumar et al. (2011), Jahan et al. (2015) and Duguma (2018) recorded a higher percentages of coagulase positive isolates as $89.7 \%, 100 \%$ and $66.67 \%$ respectively. Lower results were recorded by Ghosh et al. (2003) who found that $35.4 \%$ of isolates were coagulase positive Staphylococci spp., respectively.

Additionally, $48.6 \%$ of Staphylococcus spp. recovered from the local pasteurized milk samples were coagulase positive. Oliveira et al. (2011) attained a lower percentage of coagulase positive isolates $(30 \%)$.

Coagulase positive staphylococci are frequently involved in suppurative infections (Ryan and Ray, 2004), so the presence of these microorganisms in milk occurs especially with neglected sanitary precautions during milking.

Coagulase test was considered a primary test in identification of Staphylococcal spp. but diagnosis of these species needs many biochemical tests to guarantee a consistent results. (Quinn et al., 2002) also coagulase positive Staphylococci have the same phenotypic characters so coagulase test not considered a single species-specific biochemical test (Sasaki et al., 2010).

In the current study, most of coagulase positive Staphylococcal isolates of raw and local pasteurized milk declared a thermonuclease activity. This result was supported by many authors who found a correlation between a results of these tests (Ratner and Stratton ,1985; Kaplan, 2003 and Suarez et al., 2008). Thermo nuclease test excluded 8 and 5 of coagulase positive isolates from raw and local pasteurized milk isolates, respectively, this may be due to false-positive results of coagulase test because there are other microbial extracellular products are produced during the production of coagulase enzyme which leading to unreliable results (Buchanan and Gibbons, 1974). On other hand, Bello and Qahtani (2006) noticed that the performance of coagulase test was differed according to settings for test and experience of laboratory technicians.

Coagulase and thermonuclease tests are the criteria used by many laboratories for the identification of Staph. aureus (Kaplan 2003), but there were other coagulase and thermonuclease positive Staphylococci like (Staph. hyicus and Staph. Intermedius) (Downes and Ito, 2001 and Viçosa et al., 2010), these strains also caused intramammary infections in dairy cows and reached to milk (Roberson et al., 1996).

Voges-Proskauer is an important test in determination of Staph aureus from other coagulase and thermonuclease positive isolates (Quinn et al., 2002; Arora, 2003 and Vos et al., 2009). These findings were supported our following results, the positivity of Voges-Proskauer were recorded in 18 isolates from raw milk samples and 8 isolates from local pasteurized milk samples (Table2). Higher results were illustrated by Rusenova and Rusenov (2017) who found that $73 \%$ of coagulase positive Staphylococcal strains isolated from different animals were Voges-Proskauer positive. This variation may back to level of contamination, number of samples and method of isolation (Fagundes and Oliveira, 2004).

Most of traditional methods for the identification of Staph. aureus not reached to accurate identification for important veterinary pathogens. PCR assay can be used as a rapid and sensitive diagnostic method for diagnosis of Staph aureus in raw milk samples and it can be used in conniving accurate pasteurization methods of milk as a main food source (Brakstad et al.,1992). The PCR amplification of the nuc gene has a potential for the rapid and accurate diagnosis of Staph aureus infections (Kilic et al.,2010).

In our study, we used nuc gene primers in confirmation the presence of Staph. aureus DNA. This gene is a specific genetic marker for detection and confirmation of Staph. aureus (Hedge et al., 2013 and $\mathrm{Hu}$ et al., 2013). Furthermore, some previous studies suggested that there was a relationship between enterotoxin production and presence of nuc gene which considered as an indicator of food contamination with enterotoxigenic Staph. aureus (Tamarapu et al., 2001 and Cremonesi et al., 2005).

The data shown in table (2) and fig (2) cleared that PCR confirmed the presence of staph aureus DNA in 15 isolates and denied its existence in 3 isolates out of 18 isolates of raw milk also one isolate only of local pasteurized milk samples not confirmed as staph aureus by using specific primer (nuc gene), these results in accordance with Karahan and Cetinkaya (2007) in addition Bennett and Lancette (1998) reported that most international standards specially FDA found that PCR is the most essentially 
equivalent method in detection of Staph aureus also Speers et al. (1998) found that the sensitivity of biochemical tests was low in compared to PCR, furthermore genetic method not necessarily correspond to the same results of conservative phenotypic tests (Bosshard et al., 2004).

Staph aureus microorganisms are able to produce enterotoxins which pose a risk factor on public health (Wu et al., 2016) and most of the food industry contaminated by Staph aureus containing SEs genes, especially moist foods containing starch and protein, such as meat, poultry products and milk (Tamarapu et al., 2001).

The results postulated in Table (3) and Fig. (3) showed that SEs genes were detected in $53.33 \%$ of Staph aureus isolates from raw milk samples. This result is in agreement with this reported by Jorgensen et al. (2005), Zouharova and Rysanek (2008) and Murphy et al. (2010). Lower recovery of enterotoxigenic Staph aureus was reported by EIJakee et al. (2013) and Mansour et al. (2017) 35.7\% and $26.1 \%$ respectively. While Rahimi and Alian (2013) recorded a higher percentage of enterotoxigenic Staph aureus isolates (75\%).

On the other hand, $42.86 \%$ of Staph aureus isolates from local pasteurized milk samples were enterotoxigenic isolates (Table3 \& Fig. 4). Higher percentage was recorded by Breurec et al. (2010) 90\% while EI-Jakee et al. (2013) found that no isolate showed a positive result for enterotoxin genes.

In our study, it was noticed that sea and sed genes were the most detectable genes in most Staph aureus isolates, sec gene could be detected only in two isolate of raw milk while seb or see genes were not detected in any isolate. These results supported Rall et al. (2008) and Carfora et al. (2015).

Pasteurized milk may also be disposed to toxin production because in various situations, the shop owners turn off the chillers at night to save electricity, leaving the product exposed to different degree of temperature as cited by Chapaval et al. (2010) also the highest risk of SEs production is associated with storage the pasteurized milk at room temperature, incubation (Janštova et al., 2012).

The classical Sea and Sed genes were a common concern in cases of Staphylococcal food poisoning (Tamarapu et al., 2001). Normanno et al. (2005) found that the sea gene is the most frequent SEs genes observed among enterotoxigenic strains of Staph aureus and the more common SEs in milk (Chiang et al., 2006), the presence of Staph aureus strains have sea gene isolated from milk may be due to the bad handling during milking and packaging the products, because sea gene is more common in human isolates than animal origin (El-Baradie, 1993).
In this study, the absence of Staph aureus isolates harbored seb or see genes were recorded in previous studies (Marija et al., 2016; Karahan et al., 2009; Neder et al., 2011; EI-Jakee et al., 2013 and Rahimi and Alian, 2013).

The development of Antibiotic resistance among the bacteria poses a problem of concern. Many original studies have exposed an increasing concern towards the existence of several antibiotic resistant of Staph aureus isolates in worldwide. So, our study was concerned by determining the susceptibilities of enterotoxigenic Staph aureus isolates against different families of antimicrobials. Table (4) demonstrated that a high resistance of these isolates were recorded against penicillin $(72.73 \%)$ and tetracycline $(72.73 \%)$ followed by clindamycin $(27.27 \%)$ and erythromycin (18.18\%), while all isolates were fully susceptible to vancomycin. Our results were consolidated by Gündgan et al. (2006) Pereira et al. (2009) and Waters et al. (2011), who noticed that multidrug resistance were shown against tetracycline, Penicillin and ampicillin. Abera et al. (2010) and Thaker et al. (2013) reported a high resistance to Penicillin-G $94.4 \%$ and $100 \%$ respectively, while Asiimwe et al. (2017) reported a high resistance to tetracycline $(73.2 \%)$.

The high resistance against penicillin was explained by Lee (2003) who returned the causes to the presence of resistance genes that coded for an alteration of penicillin-binding protein $2 \mathrm{a}$ which reduced the affinity for $\beta$-lactam antibiotics, another causes were recorded by Yamamoto et al. (2013) such as Staph aureus harbor a several antibiotic resistant plasmids that may lead to the phenotypes resistance.

Additionally, the mistreatment of infection by different antibiotics in dairy farms is known to be one of the major factors responsible for the multiple drug resistant of bacteria worldwide especially ampicillin and tetracycline were the mostly used on dairy cattle (Chee-Sanford et al., 2009).

\section{CONCLUSION}

Phenotypic methods not reach to a high grade in specificity of Staph aureus identification while, PCR play a confirmative role in detection of Staphylococcus aureus and focus a light on presence of enterotoxin types of these isolates in raw and local pasteurized milk which consider a public health problem. The existence of Staph aureus resistance to some antibiotic specially penicillin in milk reflect our need to management practices and appropriate sanitary procedures to be during milking operations also we suggest the occurrence of Staph aureus in local pasteurized milk may not only back to expire 
date but attributed to improper handling and storage temperature.

\section{REFERENCES}

Abd EL-Tawab, A.A.; Abou El-Roos, A.N. and. ElGendy, M.A.A. (2015): Bacteriological and molecular studies on Staphylococcus aureus isolated from raw milk: BenhaVet. Med. J., 28(1):88-97.

Abera, M.; Demie, B.; Aragaw, K.; Regassa, F. and Regassa, A. (2010): Isolation and identification of Staphylococcus aureus from bovine mastitic milk and their drug resistancepatterns in Adama town, Ethiopia: Journal of Veterinary Medicine and Animal Health Vol. 2(3): 29-34.

Arora, D.R. (2003): Text Book of Microbiology.2nd Edition (Cultural characteristics of staphylococcus spp. (202- 2013). Publishing by Satish Kumar Jain for CBS publishers.

Asiimwe, B.B.; Baldan, R.; Trovato, A. and Cirillo, M.D. (2017): Prevalence and molecular characteristics of Staphylococcus aureus, including methicillin resistant strains, isolated from bulk can milk and raw milk products in pastoral communities of South-West Uganda: BMC Infectious Diseases: 17:422.

Balaban, N. and Rasooly A. (2000): Staphylococcal enterotoxins: Int. J. Food Microbiol.61:1-10.

Bello, C.S.S. and Qahtani, A. (2006): Pitfalls in the routine diagnosis of Staphylococcus aureus: Afr. J. Biotechnol., 4(1): 83-86.

Bennett, R.W. and Lancette, G.A. (1998): Staphylococcus aureus. Chapter 12. In: FDA's bacteriological analytical manual. 8th ed. (Revision A). Available from: http://www.cfsan.fd.gov/webam/bam-12.html.

Bosshard, P.P.; Abels, S.; Altwegg, M.; Böttger, E.C. and Zbinden, R. (2004): Comparison of conventional and molecular methods for identification of aerobic catalase-negative gram-positive cocci in the clinical laboratory: J Clin Microbiol. 42(5):2065-73.

Brakstad, O.; Aasbakk, K.G. and Maeland, J.A. (1992): Direct identification of Staphylococcus aureus in blood cultures by detection of the gene encoding the thermostable nuclease or the gene product: $\mathrm{J}$. Clin Microbiol. 30(7): 1654-1660.

Breurec, S.; Poueme, R.; Fall, C.; Tall, A.; Diawara, A.; Bada-Alambedji, R.; Broutin,C.; Leclercq, A. and Garin, B. (2010): Microbiological quality of milk from small processing units in senegal. Dis., 7(5):601-4.

Buchanan, R.E. and Gibbons, N.E. (1974): Bergey's Manual of Determinative Bacteriology. 8th ed. Williams \& Wilkins Co., Baltimore, Md. 21202.Xxvi, 1246 pp.
Carfora, V.; Caprioli, A.; Marri, N.; Sagrafoli, D.; Boselli, C.; Giacinti, G.; Giangolini, G; Sorbara, L.; Dottarelli, S.; Battisti, A. and Amatiste, S. (2015): Enterotoxin genes, enterotoxin production and methicillin resistance in Staphylococcus aureus isolated from milk and dairy products in Central Italy: International Dairy Journal 42: 12-15.

Chapaval, L.; Moon, D.H.; Gomes, J.E.; Duarte, F.R. and Tsai SM, et al. (2010): Efeito da temperatura sobre a produção de enterotoxina estafilocócica em leite. Revista Higiene Alimentar 24:180-181.

Chee-Sanford, J.C.; Mackie, R.I.; Koike, S.; Krapac, I.G.; Lin Y-F.; Yannarell, A.C.; Maxwell, S. and Aminov, R.I. (2009): Fate and transport of antibiotic residues and antibiotic resistance genes following land application of manure waste. Journal of Environmental Quality, 38(3): 1086-1108.

Chiang, C.Y.; Fan, M.C.; Liao, W.W.; Kulin, C. and Tsenh, Y. (2006): Real-Time PCR Detection of Staphylococcus aureus in Milk and Meat Using New Primers Designed from the Heat Shock Protein Gene htr Asequence: Journal of Food Protection, 70(12):2855-2859.

CLSI (2018): Performance Standards for Antimicrobial Disk Susceptibility Testing. 28th ed. CLSI standard M100.Clinical and Laboratory Standards Institute; http:/ www. facm.ucl.ac.be /intranet /CLSI/CLSI-2018M100-S28-unlocked.pdf

Cremonesi, P.; Luzzana, M.; Brasca, M.; Morandi, S.; Lodi, R.; Vimercati, C.; Agnellini, D.; Caramenti, G.; Moroni, P. and Castiglioni, B. (2005): Development of a multiplex PCR assay for the identification of Staphylococcus aureus enterotoxin strains isolated from milk and dairy products: Molecular and Cellular Probes 19 (5): 299-305.

Daka, D.; G. silassie, S. and Yihdego, D. (2012): Antibiotic-resistance isolated from cow's milk in the Hawassa area, South Ethiopia: Annals of Clinical Microbiology and Antimicrobials: 11(26), 1-6.

Donkor, E.S.; Aning, K.G. and Quaya, J. (2007): Bacterial contaminations of informally marketed raw milk in Ghana: Ghana Medical J., 41 (2): 58-61.

Downes, F.P. and Ito, H. (2001): Compendium of methods for the microbiological examination of foods. 4. ed. Washington: American Public Health Association - APHA, 676).

Duguma, A. (2018): Isolation and Identification of Staphylococcus aureus from Dairy Farms in Bishoftu Town, Ethiopia: JOJ Pub Health 3(1): JOJPH.MS.ID.555604.

EI-Jakee, J.; Marouf, S.A.; Nagwa S. Ata; Eman H. Abdel-Rahman; Sherein, I.; Abd El-Moez, Samy A.A. and Walaa E. El-Sayed (2013): Rapid method for detection of Staphylococcus 
aureus enterotoxins in Food: Global Veterinaria 11 (3): 335-341.

EL-Baradie, G.A. (1993): An avidine-biotin ELISA to determine the staphylococcal enterotoxin A in soft cheese. Alex. J. Agric. Res.38:365-378.

Fagundes, H. and Oliveira, C.A.F. (2004): Infecções intramamárias causad as por $S$. aureuse suas implicações em SaúdePública: Ciência Rural 34: $1315-1320$

Ghaleb, A.; Dauod, A.; Rateb, A. and Jamel, A.O. (2005): Prevalence of microorganism associated with intramammary infection in cows and small ruminant in the north of Palestine. J. of the Islamic University of Gaza 13(1): 165-173.

Ghosh, R.N.; Sarkar, P.B. and Batabyal, K. (2003): Characterization and hemolsyin production of coagulase positive staphylococci isolated from cattle and pigs: Indian J. Ani. Heal. 42(1): 3537.

Gündogan, N.; Citak, S. and Turan, E. (2006): Slime production, DNAse activity and antibiotic resistance of Staphylococcus aureus isolated from raw milk, pasteurized milk and ice cream samples. Food Control, 17: 389-392.

Hedge, R.; Isloor, S.; Nithin Prabhu, K.; Shome. B.R.; Rathnamma, D.; Suryanarayana, V.V.S.; Yatiraj, S.; Prasad, R.; Krishnaveni, C.; Sundareshan, N.; Akhila, D.S.; Gomes, A.R. and Hegde, N.R. (2013): Incidence of subclinical mastitis and prevalence of major mastitis pathogens in organized farms and unorganized sectors: Ind J. Microbiol. 53(3): 315-32.

Holt, J.G.; Krieg, N.R.; Sneath, P.H..; Safety, J.T. and Williams, S.T. (1993): Bergey's Manual of Determinative Bacteriology. In: Williams, K., Wilkins, O. (Eds.), Baltimore, USA, 9p.

Hu, Y.; Meng, J.; Shi, C.; Hervin, K.; Fratamico, P.M. and Shi. X. (2013): Characterization and comparative analysis of a second thermonuclease from Staphylococcus aureus: Microbiol. Res. 168 (3): 174-182.

Jahan, M.; Rahman, M.; Parvej, M.S.; Chowdhury, S.M.Z.H.; Haque, M.E.; Talukder, M.A.K. and Ahmed, S. (2015): Isolation and characterization of Staphylococcus aureus from raw cow milk in Bangladesh: Journal of Advanced Veterinary and Animal Research, 2: 49-55

Janštová B.jr.; Necidová, B.; Janštová, L. and Vorlová, L. (2012): Staphylococcus aureus growth and enterotoxin production in different types of milk HYPERLINK "https://www. researchgate.net/journal/1211-8516_Acta_ Universitatis_Agriculturae_et_Silviculturae_ Mendelianae_Brunensis" Acta Universitatis Agriculturae et Silviculturae Mendelianae Brunensis 60 (5):103-108

Jorgensen, H.J.; Mork, T.; Hogasen, H.R. and Rorvik, L.M. (2005): Enterotoxin
Staphylococcus aureus in bulk milk in Norway section for Feed and Food Microbiology. National Veterinary, Institute, Oslo, Norway. Hannah. Appl Microbiol.; 99(1): 158-166

Kaplan, N.M. (2003): Use of thermonuclease testing to identify Staphylococcus aureus by direct examination of blood cultures: East Mediterr Health J. (EMHJ) :9 (1-2):185-190.

Karahan, M. and Cetinkaya, B. (2007): Coagulase gene polymorphisms detected by PCR in Staph. Aureus isolated from subclinical bovine mastitis in Turkey. The Vet. J., 174: 428-431.

Karahan, M.; Acik, M.N. and Cetinkaya, B. (2009): Investigation of toxin genes by polymerase chain reaction in S.aureus strains isolated from bovine mastitis in Turkey: Foodborne Pathogens and Disease,6(8): 1029-1035.

Kateete, P.D.; Kimani, N.C.; Katabazi, A.F.; Okeng, I.; Okee, S.M.; Nanteza, A.L.; Joloba, M.; Florence, C. and Kateete, N. (2010): Identification of Staphylococcus aureus: DNase and Mannitol salt agar improve the efficiency of the tube coagulase test: Annals of Clinical Microbiology and Antimicrobial,9: 923.

Kilic, A.; Muldrew, K.L.; Tang, Y.W. and Basustaoglu, A.C. (2010): Triplex real-time polymerase chain reaction assay for simultaneous detection of Staphylococcus aureus and coagulase-negative Staphylococci and determination of methicillin resistance directly from positive blood culture bottles: Diagn Microbiol Infect Dis.;66(4):349-55.

Kim, J.; Kim, M. and Welstory, S. (2017): Study on the Infection of Staphylococcus aureus and Diagnostic Methods in Food, Inc., Food R\&D Center, Chapter 1 South Korea 2 Dxgene, Inc., South Korea.

Kumar, R.; Yadav, B.R. and Singh, R.S. (2011): Antibiotic resistance and pathogenicity factors in S.aureus isolated from mastitic Sahiwal cattle: J. of Biosciences, 36(1):175-188.

Lee, J.H. (2003): Methicillin (oxacillin)-resistant Staphylococcus aureus strains isolated from major food animals and their potential transmission to humans: Appl. Environ. Microbiol., 69: 6489-6494.

Mansour, A.S.; Wagih, E.G.; Morgan, D.S.; Elhariri, M.; El-Shabrawy, A.M.; Abuelnagal, M.S.A. and Elgabry, E.A. (2017): Detection of Staphylococcus aureus enterotoxin strains in bovine raw milk by reversed passive latex agglutination and multiplex polymerase chain reaction: Veterinary World, 10(8): 843-847.

Marija, P.; Stanko, P.; Branko, V.; Zoran, R.; Miodrag, N.; Aleksandra, R.V.K.; Dušan, S. and Milijana, B. (2016): Prevalence and molecular characterization of enterotoxinproducing strains of Staphylococcus aureus isolated from serbian dairy cows: Acta Veterinaria-Beograd, 66 (4): 466-477. 
Mohanty, S. and Cock, I.E. (2010): Bioactivity of Syzygiumjambos methanolic extracts: Antibacterial activity and toxicity: pharmacogency research.,2(1):4-9

Murphy, B.P.; O'mahony, E.; Buckley J.F.; O'brien, $S$. and Fanning, S. (2010): Characterization of S.aureus isolated from dairy animals in Ireland:Zoonoses Public Health, 57(4):249257.

Neder, V.E.; Canavesio, V.R. and Calvinho, L.F. (2011): Presence of enterotoxin S.aureus in bulk tank milk from Argentine dairy farms: Rev. Argent. Microbiol., 43(2):104-106.

Normanno, G.; Firinu, A.; Virgilio, S.; Mula, G.; Dambrosio, A.; Poggiu, A.; Decastelli, L.; Mioni, R.; Scuota, S.; Bolozoni, G.; Di Giannatale, E.; Salinetti, A.P.; La Salandra, G., Bartoli, M.; Zuccon, F.; Pirino, T.; Sias, S.; Parisi, A.; Quaglia, N.C. and Celano, G.V. (2005): Coagulase positive Staphylococci and S.aureus in food products marketed in Italy: Int. J. Food Microbiol., 98: 73-79.

Oliveira, L.P.; de Soares e Barros, L.S.; Silva, V.C. and Cirqueira, M.G. (2011): Study of Staphylococcus aureus in raw and pasteurized milk consumed in the Reconcavo area of the State of Bahia, Brazil: J. Food Process Technol. 2:128.

Pandy, N.; Kumari, A.; Varma, A.K.; Sahu, S.; Akbar, M.A. (2014) Impact of applying hygienic practices at farm on bacteriological quality of raw milk. Vet. World.7(9):754-758

Pereira, V.; Lopes, C.; Castro, A.; Silva, J.; Gibbs, P. and Teixeira, P. (2009): Characterization for enterotoxin production, virulence factors and antibiotic susceptibility of Staphylococcus aureus isolates from various foods in Portugal. Food Microbiol., 26: 278-282

Quinn, P.J.; Cater, M.E.; Markey, B.K. and Cater, G.R. (2002): Clinical veterinary microbiological Mosby- Year Book Europe Limited. Staphylococcus species. 118-127.

Rahimi, E. and Alian, F. (2013): Presence of enterotoxin Staphylococcus aureus in cow, camel, sheep, goat, and buffalo bulk tank milk: VeterinarskiArhiv.,83 (1): 23-30.

Rall, V.L.M.; Vieira, F.P.; Rall, R.; Vieitis, R.L.; Fernandes, A.J.R.; Candeias, J.M.G.; Cardoso, K.F.G. and Araujo, J.P. (2008): PCR detection of staphylococcal enterotoxin genes in $S$. aureus strains isolated from raw and pasteurized milk: Vet. Microbiol., 132: 408413.

Ratner, H.B. and Stratton, C.W. (1985): Thermonuclease test for same-day identification of Staphylococcus aureus in blood cultures; 21(6): 995-996.

Rehman, MU.; Rashid, M.; Sheikh, J.A. and Bhat, M.A. (2014): Molecular epidemiology and antibiotic resistance pattern of enteropathogenic Echerichia coli isolated from bovines and their handlers in Jammu, India. of advanced veterinary and animal research $1: 177-181$

Riva, A.; Borghi, E.; Cirasola, D.; Colmegna, S.; Borgo, F.; Amato, E.; Pontello, M.M. and Morace, G. (2015): Methicillin-resistant Staphylococcus aureus in raw milk: Prevalence, SCC mec typing, enterotoxin characterization, and antimicrobial resistance patterns. J. Food Prot. 78(6): 1142-1146.

Roberson, J.R.; Fox, L.K.; Hancock, D.D.; Gay, J.M. and Beser, T.E. (1996): Prevalence of coagulase -positive staphylococci, other than Staphylococcus aureus in bovine mastitis: Am J Vet Res, 57: 54-58.

Rosengren, A.; Lindblad, $M$. and Lindqvist, $R$. (2013): The effect of undissociated lactic acid on $S$. aureus growth and enterotoxin A production: Int. J. Food Microbiology.162: 159-166.

Rusenova, V.N. and Rusenov, G.A. (2017): Detection of Staphylococcus aureus among coagulase positive staphylococci from animal origin based on conventional and molecular methods: Macedonian Veterinary Review, 40, Number $1-20$.

Ryan, K.J. and Ray, C.G. (2004): Sherris Medical Microbiology (4th ed.). McGraw Hill. ISBN 08385-8529-9

Sasaki, T.; Tsubakishita, S.; Tanaka, Y.; Sakusabe, A.; Ohtsuk, M.; Hirotaki, S.; Kawakami, T.; Fukata, T. and Hiramatsu, K. (2010): Multiplex-PCR method for species identification of coagulase-positive staphylococci: J Clin Microbiol. 48, 765-769.

Shawish, R.R. and Al-Humam, N.A. (2016): Contamination of beef products with staphylococcal classical enterotoxins in Egypt and Saudi Arabia: GMS Hyg. Infect. Control, 11, Doc 08. 1):125-127.

Soomro, A.H. (2003): Isolation of Staphylococcus aureus from Milk Products Sold at sweet-meat Shops of Hyderabad: Online Journal of Biological sciences;3(1):91-94.

Speers, J.D.; Olma, R.T. and Gilbert, L.G. (1998): Evaluation of Four Methods for Rapid Identification of Staphylococcus aureus from Blood Cultures J Clin Microbiol.; 36(4): 1032-1034.

Sutejo, H.V.S.; Amarantini, C. and Budiarso, Y.T. (2017): Molecular detection of Staphylococcus aureus resistant to temperature in milk and its products, AIP Conference Proceedings 1908, 050007, 1908/1.

Suarez, M.J.; Arias, M.L. and del Mar Gamboa, M. (2008): Staphylococcus aureus enterotoxin A detection using the polymerase chain reaction (PCR) and its correlation with coagulase and thermonuclease tests Latinoam Nutr. 58(1):5963. 
Tamarapu, S.; Mckillip, J.L. and Drake, M. (2001): Development of a multiplex polymerase chain reaction assay for detection and differentiation of Staphylococcus aureus in dairy products: Journal of Food Protection 64: 664-668.

Tessema, D. and Tsegaye, S. (2017): Study on the Prevalence and Distribution of Staphylococcus aureusin raw cow milk originated from alageat vet college dairy farm, Ethiopia: J. Nutr Food Sci., 7: 2-586.

Thaker, H.C.; Brahmbhatt, M.N. and Nayak, J.B. (2013): Isolation and identification of Staphylococcus aureus from milk and milk products and their drug resistance patterns in Anand, Gujarat: Vet World,6(1):10-13.

Uddin, M.A.; Hasan, M.d. and Motazzim-ul-Haque, R.N. (2011): Isolation and Identification of Pathogenic Escherichia coli, Klebsiella spp. and Staphylococcus spp. in raw milk samples collected from different Areas of Dhaka City, Bangladesh: Stamford Journal of Microbiology. 1 (1). ISSN: 2074-5346.

Viçosa, G.N.; Moraes, P.M.; Yamazi, A.K. and Nero, L.A. (2010): Enumeration of coagulase and thermonuclease-positive Staphylococcus spp. in raw milk and fresh soft cheese: an evaluation of Baird-Parker agar, Rabbit Plasma Fibrinogen agar and the Petrifilm Staph Express count system. Food Microbiol.;27(4):447-52.
Vos, P.D. (2009): Bergeys Manual of Systematic Bacteriology (The Firmicutes). $2^{\text {nd }}$ edition, v.3, g. Staphylococcus.394-396.

Wani, S. and Bhatt, M. (2003): An epidemiological study on bovine mastitis in Kashmir valley. Ind. Vet. J. 80: 841-844.

Waters, E.A.; Contente- Cuomo, T.; Buchhagen, J.; Liu, M.C.; Watson, L.; Pearce, K.; Foster, T.J.; Bowers, J.; Engelthaler, M.E.; Keim, S.P. and Price, B.L. (2011): Multidrug Resistant S.aureus in US Meat and Poultry: Clinical Infectious Diseases, 52(10):1227-1230.

Wu, S.; Duan, N.; Gu, H.; Hao, L.; Ye, H.; Gong, W. and Wang, Z. (2016): A review of the methods for detection of Staphylococcus aureus enterotoxins. Toxins, 8(7): 176.

Yamamoto, T.; Hung, W.C.; Takano, T. and Nishiyama, A. (2013): Genetic nature and virulence of community-associated methicillin- resistant Staphylococcus aureus: Bio Medicine; 3: 2-18.

Yaniarti, NM.; Amarantini, C. and Budiarso, Y.T. (2017): The effect of temperature and Pasteurization time on Staphylococcus aureus isolates from dairy products AIP Conference Proceedings,Vol.1908, Issue 1, 10.1063-1.5012727.

Zouharova, M. and Rysanek, D. (2008): Multiplex PCR and RPLA identification of $S$. aureu enterotoxin strains from bulk tank milk. Zoonoses public Health, 55(6): 313- 319.

\section{الكثف عن جينات الاتتيروتوكسين في المكور العنقودي الذهبي المعزول من البان الأبقار \\ كاترين قلاده ، همس محمد /حمد، محد وائل عبد العظيم ، فيصل عبد اللطيف واصل}

E-mail: Katreen_Samy@hotmail.com Assiut University web-site: www.aun.edu.eg

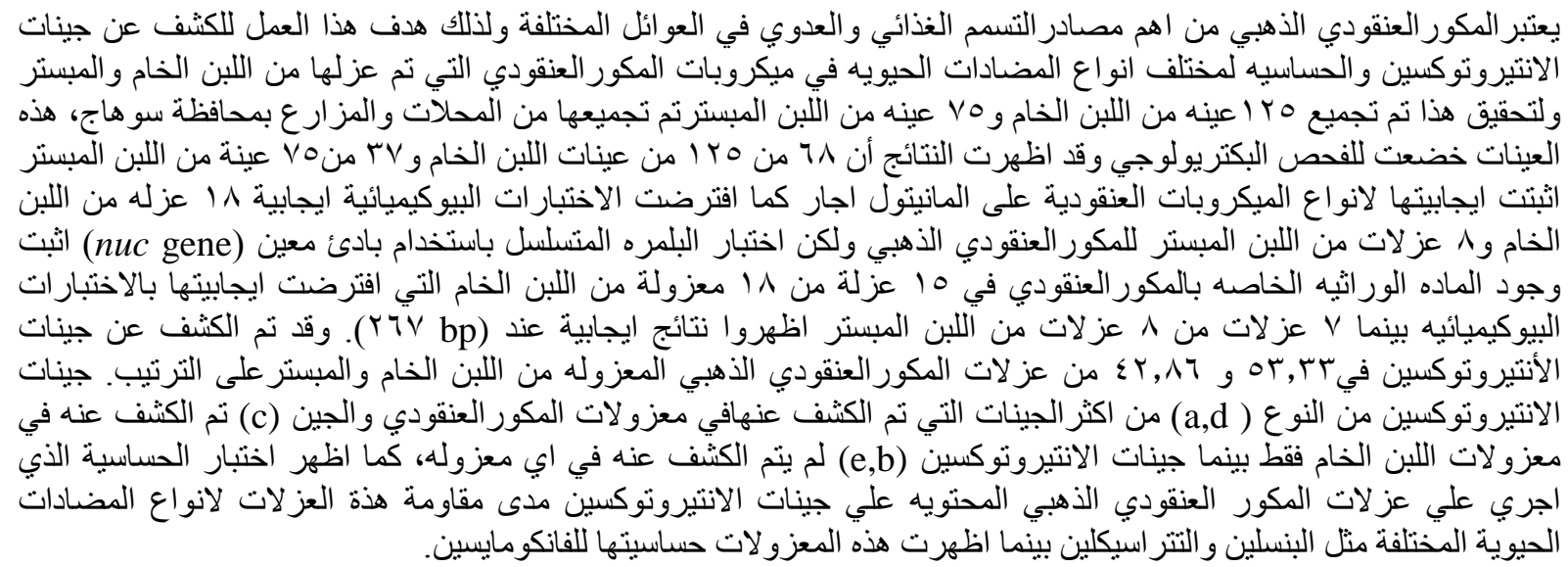

